\title{
Duration and intensity of spawning in herring Clupea harengus as related to the age structure of the mature population
}

\author{
Timothy C. Lambert \\ Marine Ecology Laboratory, Fisheries \& Oceans, Bedford Institute of Oceanography, PO Box 1006, Dartmouth, Nova Scotia \\ B2Y 4A2, Canada
}

\begin{abstract}
Herring Clupea harengus often spawns in waves which result in a succession of larval cohorts. First-time (recruit) spawners generally spawn later than repeat spawners and it is suggested that spawning proceeds consecutively through year classes from oldest to youngest due to differential maturation. Further, it is suggested it is the large reproductive contribution of dominant year classes that gives the appearance of spawning waves; thus the number and relative size of these waves relates directly to the age structure of the reproductive population. In this paper historical data on the Norwegian spring-spawning herring stock are reworked in support of the hypothesis. An age-specific progression through annual maturation stages is demonstrated. This relation gives mean time of spawning by age which, combined with information on the age frequency distribution and age-specific fecundity, allows prediction of the duration of the spawning season and the intensity of spawning over time. Predictions agree well with observations made at actual spawning sites. Furthermore, it is probable that recruitment is, in part, dependent on the age structure of the mature population. The higher the number of age classes in the reproductive population the greater appears the likelihood of good recruitment.
\end{abstract}

\section{INTRODUCTION}

It is an underappreciated fact that herring Clupea harengus often arrive at spawning grounds in runs or waves. This phenomenon has been reported in both the Atlantic and Pacific for C. h. harengus and C. h. palasii (Table 1). Discrete batches of eggs deposited by these waves of spawning herring give rise to a succession of larval cohorts (Hourston 1958, Lambert et al. 1982, Dempsey \& Bamber 1983). Having previously explored the ecological significance of the larval cohort complex (Lambert 1984, Lambert \& Ware 1984) I shall attempt, in this paper, to shed some light on the mechanism governing the behaviour from which it originates.

The hypothesis I have formulated is rooted in 2 sets of observations. Firstly, for most herring stocks, the largest fish arrive on the spawning grounds to spawn first and the smallest, first-time spawners, arrive last (Atlantic: Hodgson 1927, Lea 1929, Smith 1938, Runnstrøm 1941a, b, Tibbo 1949, Jean 1956, Day 1957. Blaxter \& Hempel 1963, Boyar 1968, Dragesund et al. 1980; Pacific: Ambroz 1931 [in Tester 1937], Motoda \&
Hirano 1963, Hay 1985). Secondly, herring have been reported schooling on the basis of length or age (Hjort 1914, Graham 1936, Tester 1937, Burd 1962, Boyar 1968).

With these observations as a starting point, I hope, in the first part of the paper, to provide evidence of a segregation by age during spawning and to show that spawning waves of herring are directly attributable to the age composition of the stock. The second part of the paper tests the hypothesis using data collected by Norwegian workers.

\section{ELABORATION OF THE HYPOTHESIS}

\section{Factors affecting timing of spawning}

A major factor determining the timing of spawning in herring is temperature (Atlantic: Berenbeim \& Sigaev 1977, Ware \& Henriksen 1978, Messieh 1978; Pacific: Hay 1985, Haegele \& Schweigert 1985). In all these cases warmer temperatures experienced by prespawn- 
Table 1 Clupea harengus. Locations of reported herring spawning waves and the separation in time between them

\begin{tabular}{|c|c|c|c|c|}
\hline Location & Year & No. of waves & $\begin{array}{l}\text { Time between waves } \\
\text { (d) }\end{array}$ & Source \\
\hline $\begin{array}{l}\text { Barkley Sound, } \\
\text { British Columbia }\end{array}$ & $\begin{array}{l}1950 \\
1982\end{array}$ & $\begin{array}{l}3 \\
3\end{array}$ & $\begin{array}{l}8,18 ? \\
14,14\end{array}$ & $\begin{array}{l}\text { Stevenson } 1962 \\
\text { Hay } 1985\end{array}$ \\
\hline $\begin{array}{l}\text { Departure Bay, } \\
\text { British Columbia }\end{array}$ & $\begin{array}{l}1950 \\
1951 \\
1952 \\
1953\end{array}$ & $\begin{array}{l}3 \\
3 \\
3 \\
3\end{array}$ & $\begin{array}{l}15,13 \\
9,9 \\
3,6 \\
11,20\end{array}$ & $\begin{array}{l}\text { Hourston } 1958 \\
\text { Hoursten } 1958 \\
\text { Hoursten } 1958 \\
\text { Hoursten } 1958\end{array}$ \\
\hline $\begin{array}{l}\text { Georges Bank } \\
\text { NW Atlantic }\end{array}$ & 1970 & 2 & 11 & Pankratov \& Sigajev 1973 \\
\hline $\begin{array}{l}\text { Nyiski Bay, Sakhalin Island, } \\
\text { NW Pacific }\end{array}$ & $\begin{array}{l}1972 \\
1973\end{array}$ & $\begin{array}{l}3 \\
3\end{array}$ & $\begin{array}{l}13,12 \\
7,13\end{array}$ & $\begin{array}{l}\text { Gritsenko \& Shilin } 1979^{\circ} \\
\text { Gritsenko \& Shilin } 1979^{\circ}\end{array}$ \\
\hline $\begin{array}{l}\text { Baie-Ste Anne. } \\
\text { SW Gulf of St. Lawrence }\end{array}$ & $\begin{array}{l}1974 \\
1975 \\
1976 \\
1977 \\
1978 \\
1978\end{array}$ & $\begin{array}{l}2 \\
3 \\
2 \\
3 \\
4 \\
4\end{array}$ & $\begin{array}{l}13 \\
7,12 \\
7 \\
7,16 \\
4,11,7 \\
5,6,14\end{array}$ & $\begin{array}{l}\text { Ware \& Henriksen } 1978^{\circ} \\
\text { Ware \& Henriksen } 1978^{\circ} \\
\text { Ware \& Henriksen } 1978^{\circ} \\
\text { Ware \& Henriksen } 1978^{\circ} \\
\text { Lambert unpubl. } \\
\text { Lambert unpubl. }\end{array}$ \\
\hline $\begin{array}{l}\text { St Georges Bay, } \\
\text { SE Gulf St. Lawrence }\end{array}$ & 1977 & 3 & 22,14 & Lambert $1984^{\circ}$ \\
\hline $\begin{array}{l}\text { Blackwater Estuary, } \\
\text { Southern North Sea }\end{array}$ & 1979 & 3 & 6.21 & Dempsey \& Bamber 1983 \\
\hline $\begin{array}{l}\text { Peter the Great Bay, } \\
\text { USSR (Pacific herring) }\end{array}$ & $1931 ?$ & 4 & - & $\begin{array}{l}\text { Ambroz } 1931 \text { quoted in Lebedev } \\
1969\end{array}$ \\
\hline $\begin{array}{l}\text { Bay of Chaleur, } \\
\text { W Gulf of St. Lawrence }\end{array}$ & $\begin{array}{l}1952 \\
1953 \\
1954\end{array}$ & $\begin{array}{l}4 \\
3 \\
2\end{array}$ & $\begin{array}{l}17,17,18 \\
16,35 \\
34\end{array}$ & $\begin{array}{l}\text { Data of Jean } 1956 \text { used in Lambert } \\
1984^{\circ}\end{array}$ \\
\hline $\begin{array}{l}\text { Milford Haven, } \\
\text { Wales }\end{array}$ & $\begin{array}{l}1981 \\
1982\end{array}$ & $\begin{array}{l}2 \\
2\end{array}$ & $\begin{array}{l}? \\
15\end{array}$ & $\begin{array}{l}\text { Clarke \& King } 1985 \\
\text { Clarke \& King } 1985\end{array}$ \\
\hline $\begin{array}{l}\text { Isle Verte, } \\
\text { St. Lawrence Estuary }\end{array}$ & 1979 & 2 & 20 & Auger \& Powles 1980 \\
\hline $\begin{array}{l}\text { Firth of Clyde, } \\
\text { Western Scotland }\end{array}$ & 1958 & 2 & 26 & Parrish et al. 1959 \\
\hline
\end{tabular}

ing herring led to early spawning, whereas cooler temperatures delayed spawning

A more subtle effect on time of spawning is that of age/size of fish. This can be shown using data on the SW Gulf of St Lawrence herring stock (Table 2). Using multiple regression, the effects of fish size and sea surface temperature (SST) on the mean day of arrival (MDA) of herring at the spawning ground were examined. As expected, temperature is the dominant factor, on average explaining over a period of $12 \mathrm{yr}$ about $63 \%$ of the variability in MDA, with length explaining an additional 1 to $5 \%$ (Table 3 ). To remove the overwhelming effect of temperature, I considered 4 yr in which SST was virtually identical: $1950,5.1^{\circ} \mathrm{C}$; $1956,5.2^{\circ} \mathrm{C} ; 1962,5.0^{\circ} \mathrm{C}$ and $1965,5.0^{\circ} \mathrm{C}$. Overall $(3$ counties, $n=12), 59 \%$ of the variability in $M D A(y)$ was explained by mean length $(x) ; y=182.6-0.15 x_{1}$ $r=-0.77, p<0.01$ (Fig. 1). Thus, in years when the average length of the stock is high, spawning tends to be earlier than in years when fish are smaller

This length or age effect can be seen within a single spawning season. As mentioned in the introduction, the observation that repeat spawners spawn before recruit spawners has been often reported. Once again Gulf of St Lawrence herring can be used as an example. These herring overwinter off the west and south coasts of Newfoundland and undergo an annual migration during April-May across the Gulf of St Lawrence 
Table 2. Clupea harengus. Herring stock in the SW Gulf of Lawrence. Mean May surface temperature at Entry Island, Magdalen Islands, mean length of herring in New Brunswick spring herring fishery (Tibbo et al. 1969) and mean day of arrival of spring herring at spawning grounds in 3 counties (Ware \& Henriksen 1978) N.B. Some or all of data unavailable in years missing from the series

\begin{tabular}{|c|c|c|c|c|c|}
\hline \multirow[t]{2}{*}{ Year } & \multirow[t]{2}{*}{ Temp. $\left({ }^{\circ} \mathrm{C}\right)$} & \multirow[t]{2}{*}{ Mean length (mm) } & \multicolumn{3}{|c|}{ Mean day (Julian) of arrival } \\
\hline & & & Kent & Northumberland & Prince \\
\hline 1950 & 5.1 & 327 & 135.3 & 135.0 & 134.5 \\
\hline 1951 & 6.0 & 323 & 130.3 & 125.9 & 127.2 \\
\hline 1952 & 5.6 & 322 & 134.5 & 135.0 & 134.8 \\
\hline 1953 & 6.6 & 323 & 132.9 & 128.8 & 132.1 \\
\hline 1954 & 5.4 & 326 & 131.4 & 134.6 & 132.0 \\
\hline 1955 & 5.5 & 292 & 134.6 & 134.6 & 134.3 \\
\hline 1956 & 5.2 & 312 & 136.8 & 134.3 & 133.7 \\
\hline 1960 & 7.4 & 314 & 134.2 & 135.1 & 139.4 \\
\hline 1961 & 2.4 & 312 & 163.8 & 153.1 & 162.3 \\
\hline 1962 & 5.0 & 286 & 140.5 & 137.4 & 144.0 \\
\hline 1965 & 5.0 & 306 & 137.8 & 136.2 & 138.2 \\
\hline 1966 & 5.5 & 309 & 138.5 & 139.2 & 143.3 \\
\hline
\end{tabular}

Table 3. Clupea harengus. Effect of water surface temperature (mean value for May measured at Entry Island, Magdalen Islands) and mean body length, on the mean day of arrival (MDA) at southwest Gulf of St. Lawrence spawning grounds for autumnspawning herring. Values are $\mathrm{r}^{2}$ and significance level (in brackets) from multiple regression

\begin{tabular}{lccr|}
\hline County & MDA $\times$ Temp. & MDA $\times$ Length & MDA $\times$ Temp. $\times$ Length \\
\hline Prince & $0.52(0.008)$ & $0.12(0.273)$ & $0.57(0.023)$ \\
Northumberland & $0.64(0.002)$ & $0.07(0.395)$ & $0.65(0.003)$ \\
Kent & $0.72(0.001)$ & $0.06(0.441)$ & $0.73(0.003)$ \\
\hline
\end{tabular}

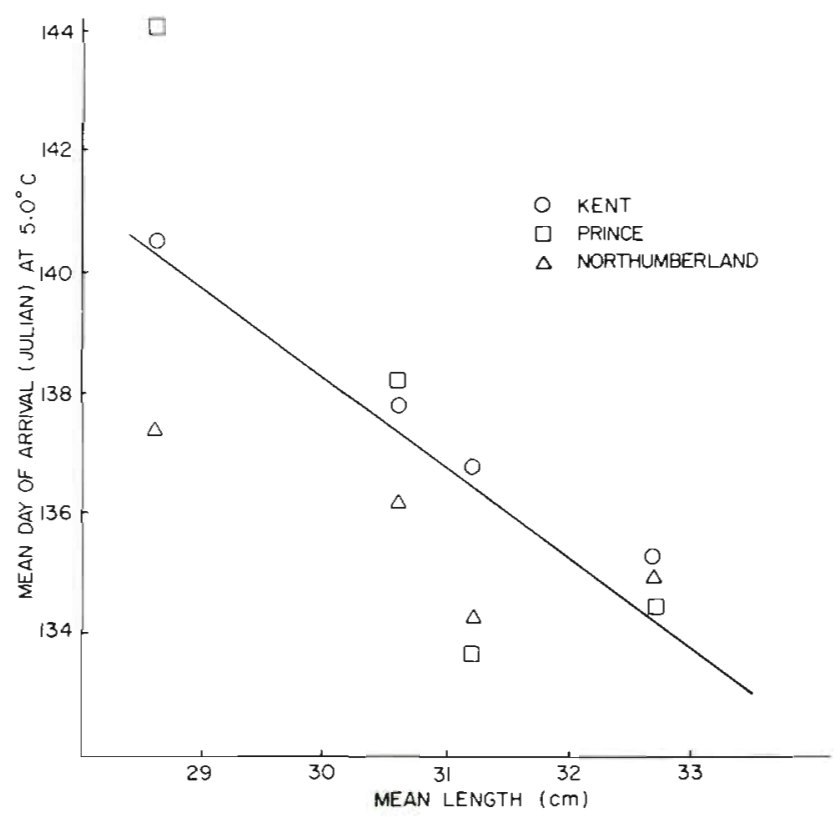

Fig. 1. Clupea harengus. Relation of body length to arrival time of spring-spawning herring at spawning grounds in the southwest Gulf of St Lawrence. Data derived from landings in 3 counties
Table 4. Clupea harengus. Herring stock in the southern Gulf of Lawrence. Age at spawning. Data from Day (1957)

\begin{tabular}{|llll|}
\hline Location & \multicolumn{1}{c}{ Date } & $\begin{array}{c}\text { Mean length } \\
(\mathrm{cm})\end{array}$ & $\begin{array}{c}\text { Mean age } \\
(\mathrm{yr})\end{array}$ \\
\hline Shediac, New & Mid May 1946 & 31.2 & 6.9 \\
Brunswick & Late May 1946 & 27.3 & 3.9 \\
North Rustico, & May 1946 & 29.6 & 6.0 \\
Prince Edward & June 1946 & 27.0 & 3.8 \\
Island & Mid May 1947 & 30.1 & 5.4 \\
& Late May 1947 & 29.1 & 4.8 \\
\hline
\end{tabular}

to spawning grounds off the Gaspé peninsula and eastern New Brunswick (Winters \& Becket 1978). The decline in age during the spawning season, often reported elsewhere, also occurs in this area. For example Table 4 shows data from Day (1957).

Reworked data of Jean (1956) clearly demonstrate this seasonal decline for Gulf herring (Fig. 2). Both spring and autumn stocks exhibited a significant decrease in average length during the spawning season. Given Day's (1957) and Jean's (1956) data it seems probable there is a gradual decrease in the age of spawning fish over the spawning season. 


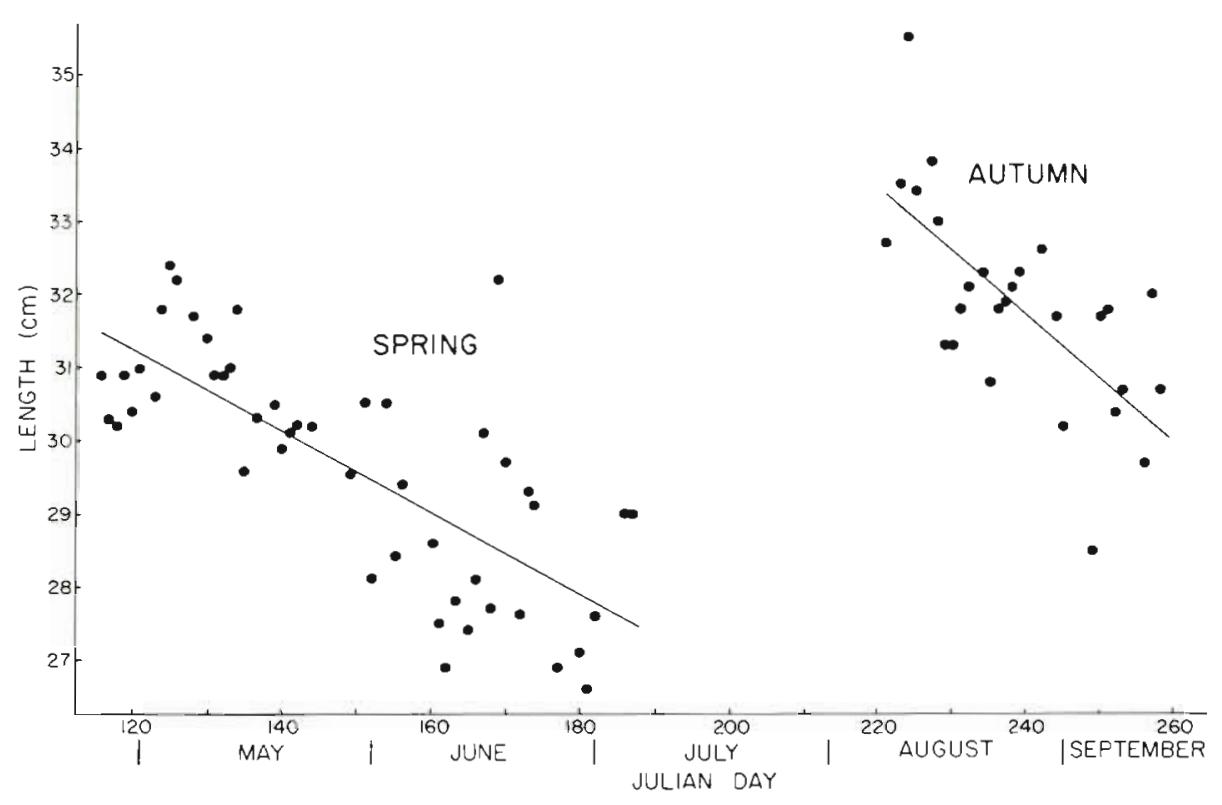

Fig. 2. Clupea harengus. Size of herring upon arrival at spawning grounds at Grande Riviere, Quebec, 1954; illustrating the decrease in body length during spring $(\mathrm{y}=37.6-0.05 \mathrm{x} ; \mathrm{n}=48$, $\mathrm{r}=-0.73, \mathrm{p}<0.001)$ and fall $(\mathrm{y}=51.45-0.08 \mathrm{x} ; \mathrm{n}=27, \mathrm{r}=$ $-0.67, p<0.001$ ) spawning season. (Drawn from data of Jean 1956)

\section{Age-specific maturation}

Early arrivals at spawning grounds (SW Gulf of St. Lawrence) are reported to be predominantly male (Escuminac Cooperative roe-processing plant: Theodore Williston, Hardwicke, New Brunswick, pers. comm.; Caribou, National Sea Products processing plant, 60 to $62 \%$ male, B. L. Henriksen, unpubl. data on hand at Marine Ecology Lab., Dartmouth; and British Columbia: Hay 1985). Therefore, the fact that males mature earlier than females (Blaxter \& Holliday 1963, Hay 1985) suggests a link between the annual maturation cycle and arrival at the spawning grounds. But is there evidence of a differential rate or differential initiation of maturation with respect to age or length? Maturation stages and age at first maturity of herring have been documented extensively, but data on the annual gonad maturation cycle of mature fish with respect to age/length are scarce. However, those that are available are supportive of a link between differential maturity and spawning time.

From samples of herring collected on the SW coast of Norway over 4 mo (prior to and during the spawning season) Runnstrom (1941a) reported that younger groups reached maturity later than older spawners. Of this same herring stock Rasmussen (cited in Runnstrom 1941a) reported that the average state of maturity observed in successive catches decreased during the spawning season; which, he felt, implied the advent of fresh shoals. Again of the Norwegian stock, Dragesund (1970) reported that repeat spawners reached maturity Stages VI (running) and VII (spent) earlier than recruits. This suggests recruits spawned later than repeat spawners.
Hay (1985) demonstrated that the gonadosomatic index (GSI) of Pacific herring increased more rapidly in larger females than smaller females. This change of GSI over time can be used to predict the time of spawning (D. M. Ware, Pacific Biological Station, Nanaimo, British Columbia, pers. comm.).

Data on Manx herring collected by Smith (cited and analysed by Iles 1964) show clearly that older fish begin the maturation process earlier in the year than younger fish. However, Iles (1964) states that 'The older fish reach Stage $V$ earlier and remain in it longer which would tend to prevent age (or length) groups from spawning as units'. This can be more or less true, depending on the time scale one uses when viewing the data. Units that are resolvable on a scale of weeks would merge into one on a scale of months. Notwithstanding Iles' conclusions, his analysis does show a $12 \mathrm{~d}$ difference in the arrival at Stage VI (spawningflowing roe and milt) between Age 2 and Ages 4 and 5 . As will be shown, this time interval is entirely consistent with the separation between spawning waves. Blaxter \& Hunter (1982) suggest timing of reproduction may be affected by population structure since 'smaller fish often become sexually active later in the year than do larger ones'.

Another pelagic species, Atlantic mackerel Scomber scombrus, although not a demersal spawner, exhibits notable similarities in spawning behaviour. As in the case of herring, S. scombrus males mature before females (Dawson 1986) and older, larger fish mature before younger, smaller fish and are the first to arrive and commence spawning (Lockwood et al. 1981, Dawson 1986). Other species displaying a similar succession of age during the spawning season are trout Salmo 
trutta (Elliot 1984), plaice Pleuronectes platessa (Simpson 1959), and blue whiting Micromesistius poutassou (J. Daan unpubl., cited in Dawson 1986).

\section{Age structure in relation to maturation}

If one assumes the oldest fish spawn first, followed by successively younger classes in an orderly progression, then the pattern of spawning ought to be related to the age structure of the mature population. For instance, if all year classes were of equal magnitude, then spawning would begin with the oldest fish and proceed at a more or less equal intensity until the youngest, recruit spawners, had spawned. But this could rarely be so, as there are normally one or more predominant year classes in any spawning population. For a number of Pacific and Atlantic herring stocks, comprising spring summer and autumn spawners, Lambert (unpubl.) ennumerated peaks in annual age frequency curves, where a peak was considered to be any point flanked by lower values (Cole 1951, Raup \& Sepkowski 1984). The mean number of peaks per curve ranged from 1.3 to 3.2 with an overall mean of 2.5 . (The mean interval between these peaks ranged from 2.2 to $4.6 \mathrm{yr}$ with an overall mean of $3.1 \mathrm{yr}$ ). Referring back to Table 1, note that the mean number of spawning waves $(n=25)$ is 2.8 , strikingly similar to the overall mean value of age frequency peaks. Now if, for example, the age frequency of a mature population is trimodal and each year class spawns in turn, from oldest to youngest, there will be 3 periods of increased spawning intensity corresponding to the 3 larger year classes. There would be, in effect, 3 spawning waves.

\section{SUPPORT FOR THE HYPOTHESIS}

I have suggested that there is an age segregation during spawning of Clupea harengus; the oldest fish spawn first followed by an orderly progression of successively younger year classes until the last (recruits) have spawned. Furthermore, spawning waves are but a reflection of the unequal magnitude of year classes within the mature stock.

The data used to test this hypothesis were collected by Norwegian researchers in the 1930's and reported by Runnstrøm $(1941 \mathrm{a}$, b). I have focussed on one year, 1934, when the data are most comprehensive. Information is provided on the duration and intensity of egg deposition from grab samples taken on spawning grounds together with details of the adult population responsible for this spawning, including most importantly, information on age-specific maturation.

\section{Spawning site}

During the '30's the major spawning grounds of Norwegian spring spawners were along the southwest coast of Norway, south of Bergen. The most important region was a bank of about $145 \mathrm{~km}^{2}$ along the west and south coast of the island of Karmøy just NE of Stavanger (Fig 3). The total spawning area sampled in 1934 was about $300 \mathrm{~km}^{2}$ and herring roe was found from 5 to $150 \mathrm{~m}$, but by far the greatest densities occurred from 40 to $70 \mathrm{~m}$ depth.

Runnstrøm (1941b) collected herring eggs with a Petersen grab, noted their stage of development and, using information on rate of development provided by laboratory studies, backcalculated the time of deposition of the eggs. Fig. 4 shows occurrence of newly laid eggs in 10 subareas of the spawning grounds. The distribution of eggs was supported by observations from the first systematic acoustic survey in 1937 (Runn-

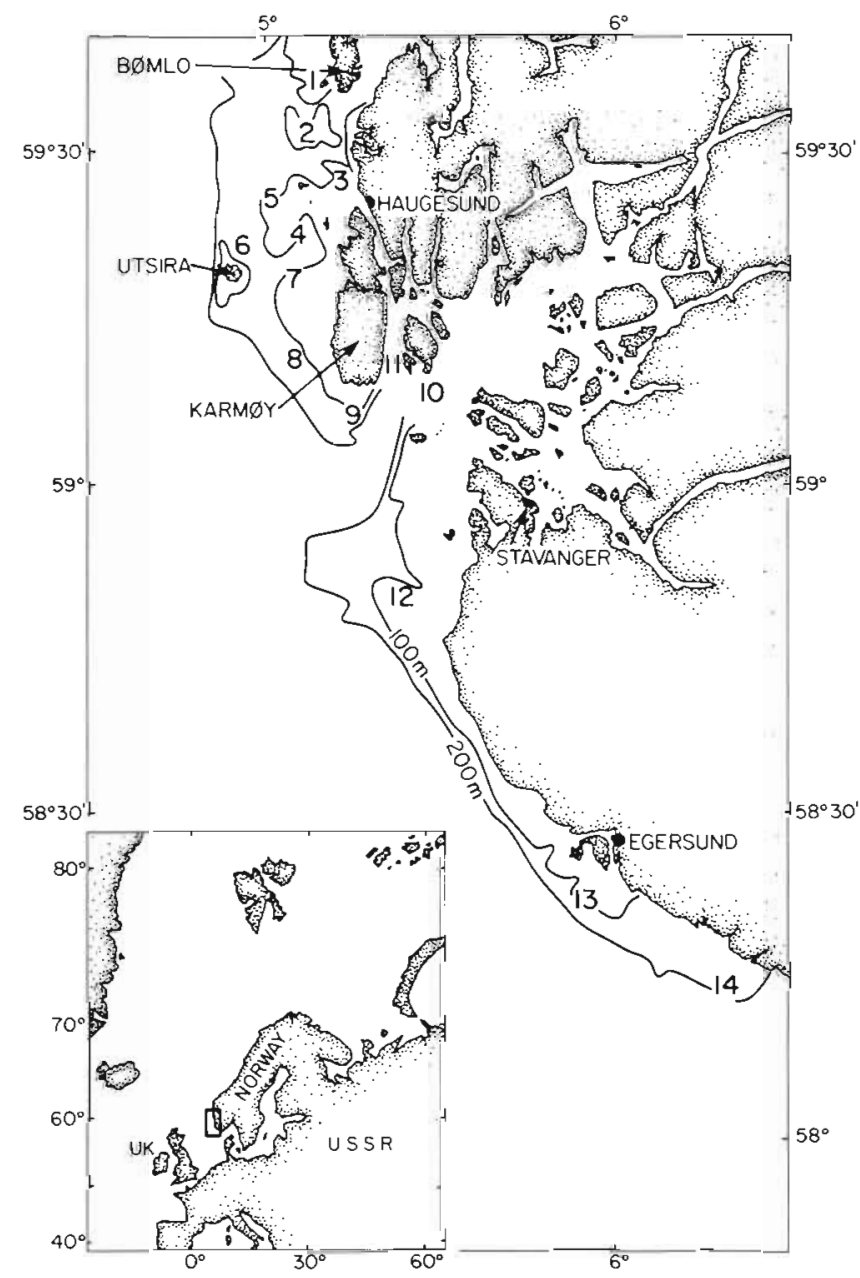

Fig. 3. Location of spring herring spawning beds off southwest Norway. Numbers refer to sampling areas of Runnstrom (1941b). After Harden-Jones (1977) 


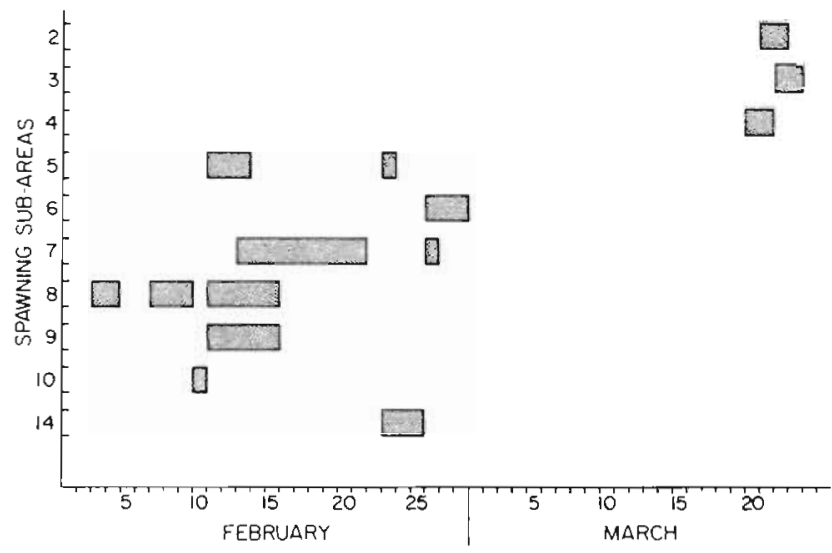

Fig. 4. Clupea harengus. Occurrence of newly deposited herring eggs off southwest Norway, 1934. Numbered sampling areas as in Fig. 3. From data of Runnstrom (1941b)

strøm 1941b) which indicated an inshore movement of herring schools which, when they reached the coastal banks, dispersed both north and south. In the case of 1934 (Fig. 4) herring appear to have reached the banks around Subarea 8 from which the north and south spread occurs. The majority of herring which spawned in the northerly areas near Bømlo were recruit spawners.

\section{Age-specific maturation}

Runnstrom (1941a) provides 2 figures (10a and 10b) which show the age composition of herring in different maturity stages for a 5 mo period prior to and during the spawning period. Using data from these figures I calculated a weighted mean time at which most of the fish of any particular age were at any particular stage. Taking the mid-point of each month and 1 Jan for one sample period denoted December-January (this was done since no actual sample dates were given by Runnstrøm), I weighted these dates with the age group numbers within each maturity stage. The numbers of fish at age in any particular maturity stage each month was equal to the proportion indicated on the graph multiplied by the total number of fish in that particular stage of maturity. For clarity an example is presented in Table 5 .

The calculated mean dates by age for 3 development stages (Stages V, prespawning-ripe; VI, spawning-running; VII, postspawning-spent) are listed in Table 6 and are presented graphically in Fig. 5.

The position of the Stage VII (spent) line (Fig. 5) is likely not so accurate, particularly at the low age end where it runs into the Stage VI line, for 2 reasons. First, sampling ended before many fish (particularly younger age classes) had reached the spent stage; and second, spent fish tend to leave the spawning area (where the
Table 5. Clupea harengus. Calculation of weighted mean date of fish stages, with an example

Sampling dates (Julian day) to be weighted

$\begin{array}{lr}\text { Dec-Jan } & 1 \\ \text { Mid Feb } & 45 \\ \text { Mid Mar } & 75 \\ \text { Mid Apr } & 105\end{array}$

Weighted mean date, $W \bar{D}=\sum_{i=1}^{4} \frac{\left(N_{i} D_{i}\right)}{\sum N_{i}}$ (1)

where $N_{1}=$ number by month (i) $D_{i}=$ sample date (Julian day) by month (i)

\section{Example for Age 11, Stage VI}

Numbers by month, given as proportion of stage (total no. in that stage), were:

\begin{tabular}{|c|c|c|c|}
\hline Dec-Jan & Feb & Mar & Apr \\
\hline 0 & $0.29(665)$ & $0.11(249)$ & $0.01(94)$ \\
\hline
\end{tabular}

Table 6. Weighted mean date (SD) in Julian days, 1934, at which most of Norwegian spring herring (by age group) were in spawning stages: V, ripe; VI, running; VII, spent

\begin{tabular}{|c|c|c|c|c|c|c|}
\hline \multirow{2}{*}{$\frac{\text { Age }}{3}$} & \multicolumn{2}{|c|}{ Stage V } & \multicolumn{2}{|c|}{ Stage VI } & \multicolumn{2}{|c|}{ Stage VII } \\
\hline & 75.0 & & 99.0 & (12.6) & 85.0 & $(14.8)$ \\
\hline 4 & 75.0 & & 84.2 & $(20.4)$ & 88.7 & $(15.1)$ \\
\hline 5 & 33.3 & $(36.9)$ & 90.3 & (16.9) & 90.2 & (15.5) \\
\hline 6 & 10.4 & $(24.5)$ & 73.8 & $(16.9)$ & 80.3 & (12.4) \\
\hline 7 & 10.1 & $(24.2)$ & 51.7 & $(13.2)$ & 75.0 & $(19.0)$ \\
\hline 8 & 5.4 & $(15.0)$ & 55.2 & (14.3) & 75.5 & ( 8.4$)$ \\
\hline 9 & 5.6 & (16.6) & 53.7 & $(14.1)$ & 74.8 & $(7.5)$ \\
\hline 10 & 6.9 & (18.8) & 53.9 & (13.8) & 73.4 & $(8.5)$ \\
\hline 11 & 4.4 & $(12.8)$ & 48.9 & $(10.5)$ & 72.7 & $(10.5)$ \\
\hline 12 & 5.1 & $(14.2)$ & 48.2 & $(9.3)$ & 72.4 & $(8.5)$ \\
\hline 13 & 1.7 & $(5.6)$ & 49.7 & (11.1) & 66.8 & $(14.0)$ \\
\hline 14 & 3.4 & $(10.4)$ & 49.0 & $(10.6)$ & 72.3 & $(16.2)$ \\
\hline 15 & 3.3 & $(10.4)$ & 48.7 & $(10.6)$ & 69.0 & (13.4) \\
\hline \multirow[t]{2}{*}{16} & 6.4 & $(17.5)$ & 50.1 & $(11.3\}$ & 62.8 & $(16.8)$ \\
\hline & \multicolumn{2}{|c|}{$\bar{x}=17.2(8.3)$} & \multicolumn{2}{|c|}{$\bar{x}=13.3(3.1)$} & \multicolumn{2}{|c|}{$\bar{x}=12.9(3.7$} \\
\hline
\end{tabular}

fishery was carried out) soon after spawning so their numbers would be underestimated. Nevertheless the Stage VII curve is included to show that its form is consistent with the 2 earlier stages.

In the figure, time is placed on the $\mathrm{x}$-axis to facilitate comprehension of the relation; however, for ease in computing time of spawning, time is better placed as the dependent variable. The relation then becomes for Stage VI

$$
y=158.79 x^{-0.461} \quad r=0.92, p<0.001
$$

where $y=$ Julian day; $x=$ age $(y r)$. These data support 


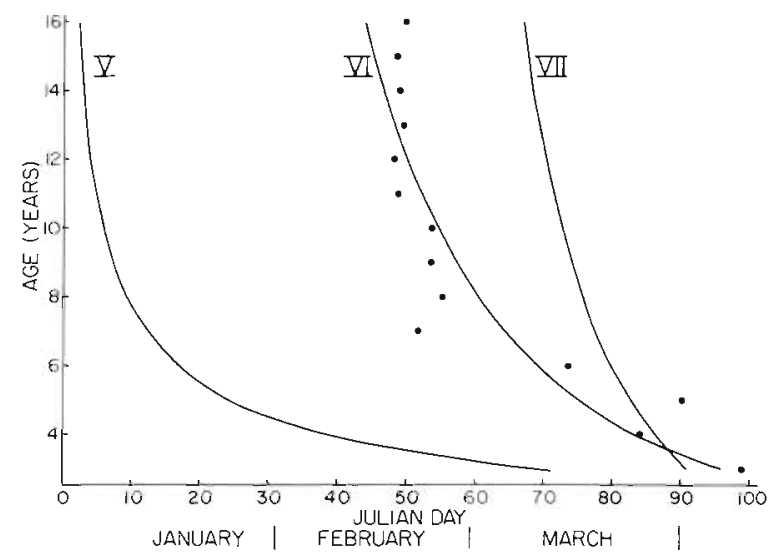

Fig. 5. Clupea harengus. Weighted mean date for peak of maturation Stages V, VI and VII by age for Norwegian spring spawning herring, 1934. See text for method of calculation and parameters. $y=a x^{b} ; r$ values for $V, V I$ and VII are -0.91 , -0.92 , and -0.91 respectively. In all cases, $p<0.001$ Points for VI curve only included. From data of Runnstrom (1941a)

the hypothesis very well; clearly the oldest fish spawn first and the youngest last. In this particular year, for instance, a 16 yr old fish would on average spawn on about 13 Feb (Day 44) and a 5 yr old, on about 16 Mar (Day 75).

Although the data fit the curves exceptionally well $\left(\mathrm{r}^{2}\right.$ in all cases greater than 0.80) and give the hypothesized inverse relation between age and spawning time, it is worthwhile checking to see if the curves are realistic before proceeding to use them for predictive purposes. This can be done in 3 ways.

First, one would expect the maturation cycle to be related to the size or weight of fish since it has been clearly demonstrated that age of first maturity for herring is size dependent (Motoda \& Hirano 1963, Dragesund et al. 1980, Ware 1985). The size or weight difference between adjacent ages is greater for younger fish than for older fish, thus one would expect more time between the spawning of younger age classes than between older age classes. The form of the curves (Fig. 5) supports this. For example, the average time between the spawning of a $15 \mathrm{yr}$ old and a $16 \mathrm{yr}$ old fish would be $1 \mathrm{~d}$ and the average time between the spawning of a 4 yr old and a 5 yr old fish, $8 \mathrm{~d}$.

Second, the duration of the spawning season of Norwegian spring herring is in the order of 4 to 6 wk (Dragesund 1970) when the stock is in a reasonably healthy (not overexploited) state. The bulk of such a stock would fall in the 5 to 16 yr old range; the relation derived here indicates about a $32 \mathrm{~d}$ interval between the mean spawning dates of these 2 ages.

Third, the spacing between spawning waves ranges from about 1 to $3 \mathrm{wk}$ (Table 1). As noted earlier, the average interval between peaks in year classes is $3.1 \mathrm{yr}$; from Fig. 5, the interval between the spawning

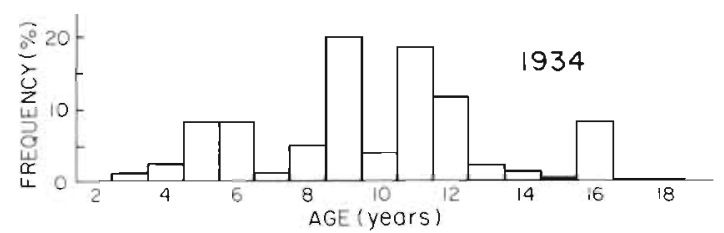

Fig. 6. Clupea harengus. Age composition of Norwegian spring spawning herring, 1934. After Runnstrøm (1941b)

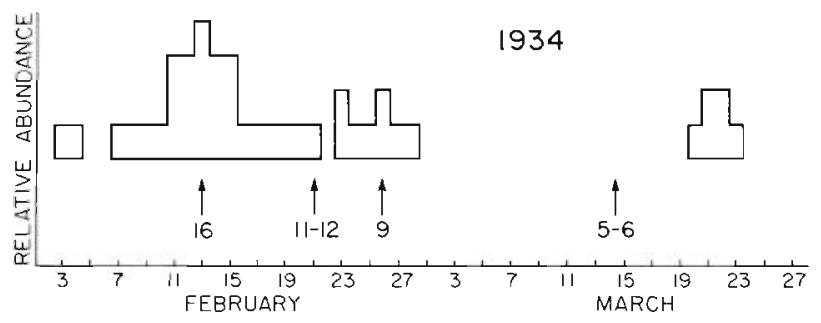

Fig. 7. Clupea harengus. Relative abundance of spawn ot Norwegian spring herring, 1934. Arrows denote predicted times of spawning for age classes which appear as peaks in Fig. 6

of $16 \mathrm{yr}$ old to $13 \mathrm{yr}$ old herring is $5 \mathrm{~d}$ and for $6 \mathrm{yr}$ old to 3 yr old is $26 \mathrm{~d}$.

Thus all 3 criteria suggest that the curves are indeed realistic.

\section{Age composition and prediction of spawning time}

The age composition of the 1934 spring herring population is given in Fig. 6 . There is a wide range in age classes with 4 peaks occurring at 5-6 yr, 9 yr, 11-12 yr, and 16 yr.

Although there can be considerable variability in the thickness of layers of eggs deposited on the bottom (Lea 1930, Runnstrøm 1941b), large numbers of herring spawning around the same time appear to spread out their eggs rather than pile them up in thick layers (Johannessen 1986); area of spawning grounds is reduced when stock numbers decline (Dragesund 1970, Anthony \& Waring 1980). Thus, on the assumption that a large influx of spawning herring would be detected at more locations than would a small influx of herring, I constructed Fig. 7 which depicts the duration and intensity of spawning in 1934 over the southern spawning area; it is a composite of Fig. 4 (sums of occurrences of newly laid eggs per day). Runnstrøm does not provide enough detailed data on egg deposition to allow a more accurate quantification; however, I feel this relative abundance index gives a reasonable picture of the spawning season.

Similarities in Fig. 6 \& 7 are evident. Like Fig. 6, Fig. 7 also has 4 peaks (at 13 Feb, 23 Feb, 26 Feb and 21-22 Mar). Remember that according to theory, the 
right end of Fig. 6 should correspond to the left end of Fig. 7. Notice that most of the egg deposition is during the early part of the spawning season; this makes biological sense, for the fecundity of the older fish is much greater than the younger so their contribution to spawning is proportionally higher. Parrish \& Saville (1965) showed the fecundity of a 16 yr old herring to be almost 3 times greater than that of a 3 yr old.

The time of spawning can be predicted for each year class by using the empirical relation of Fig. 5. Thus the predicted time of spawning for the 4 age peaks (Fig. 6) was calculated and marked by the arrows in Fig. 7 . Despite about $1 \mathrm{wk}$ mismatch for the 5-6 yr old peak, the fit is remarkably good considering there are other factors determining actual release of eggs.

Spawning of Norwegian spring herring can be delayed or disrupted by intrusions of low salinity or cold water (Runnstrøm 1941b). Also, there are undoubtedly behavioural factors which play a role in release of spawning products. Such might have the case in 1986 when autumn herring in spawning (running) condition milled around their spawning ground, Fishermans Bank in the eastern end of Northumberland Strait, southern Gulf of St Lawrence, for over a week before they actually spawned (pers, obs.). Physical conditions did not appear to be different from years of normal spawning'.

The maturation curves (Fig. 5) can only be constructed for 1934 as maturation by age data were only available for that year. The curves are undoubtedly temperature dependent so this additional factor needs to be incorporated in the relation before it can be of general use. Nevertheless, the 1934 maturation curve predicts spawning surprisingly well in years 1935 to 1937 during which period egg deposition and age composition data are available. Also, as the hypothesis predicts, the duration of the spawning season decreased ( 48 to $31 \mathrm{~d}$ ) as the number of age classes in the parent population was reduced (13 to 10 ).

\section{DISCUSSION}

Two other possible causes for the spawning wave phenomenon need to be considered. These are differential migration and lunar influence. It is well known that herring are a highly migratory species, annually moving in an orderly sequence between spawning, feeding and wintering areas. The extent of this migration can be less than $10 \mathrm{~km}$ for 'resident' stocks and up to $3000 \mathrm{~km}$ for stocks such as the Atlanto-Scandian herring (Harden-Jones 1977. Haegele \& Schweigert 1985). Swimming speed is generally a function of body length (Alexander 1967. Ware 1978); therefore, larger fish ought to swim faster and hence cover the migratory route in a shorter time. Hjort (1914) believed that when herring move against a current during migration, the smaller fish would lag behind thus resulting in a sorting according to size. The closely related anadromous alewife Alosa pseudoharengus, which, like herring also often schools according to size, when sampled at one river location during its spawning migration not only displayed a decrease in age (and thus length) over time, but also a decrease in the length-at-age over time (Libby 1982).

However, a differential migration rate as the cause of spawning waves is hard to substantiate. A great inconsistency lies in the lack of relationship between length of migration and spacing between spawning waves. The greater the distance the fish must travel from overwintering grounds to spawning ground the greater should be the time between spawning waves. This is not so as is illustrated in Table 7 where I have selected as example 3 stocks; two at the extremes, and one intermediate on a scale of distance migrated. It is clear there is no correlation between the spacing of spawning waves and the length of the migratory route.

Furthermore, even within one stock, the high annual variation in time between waves (Table 1) appears to preclude a mechanism involving differential rate of migration

In addition, a number of stocks aggregate close to the spawning area for some time before actually moving on to the grounds to spawn. For example, there is a prespawning congregation of Norwegian spring herring just offshore lasting about a month before the fish move the final few kilometres into the coast to spawn (Aasen 1962, Baker 1978). Any size segregation that might have occurred during the migration to this marshalling area would be obliterated, at least in a temporal sense. Similarly, for autumn-spawning herring off Nova Scotia, the final movement onto spawning grounds is very brief (Stobo 1982). In this case the fish spend the summer feeding in an area immediately adjacent to the spawning ground. Thus for these 2 herring stocks the last leg of the migration, the movement inshore immediately prior to spawning, is very short and variations in swimming speeds over such distances would result in negligible differences in arrival time at the spawning ground for different size fish.

It is often assumed there is a lunar influence on spawning runs of herring. However, the evidence is for the most part hearsay and anecdotal and the few published studies on the subject are contradictory or find no effect.

Hickling (1946) in a study of Milford Haven, UK, herring found no effect except sometimes decreased catches during full moon in the latter part of September, which in this case is irrelevant since these are spring-spawning fish. 
Table 7. Clupea harengus. Time between spawning waves and distance from overwintering grounds compared for 3 herring stocks

\begin{tabular}{|lcccc|}
\hline Stock & $\begin{array}{c}\text { No. of } \\
\text { spawning waves }\end{array}$ & $\begin{array}{c}\text { Time between } \\
\text { waves (d) }\end{array}$ & $\begin{array}{c}\text { Distance from overwin- } \\
\text { tering to spawning } \\
\text { ground (km) }\end{array}$ & Source \\
\hline Norwegian (1934) & 3 & 12,24 & 1500 & Runnstrom 1941a, b \\
Gulf of St. Lawrence (1975) & 3 & 7,12 & 460 & Ware \& Henrikson 1978 \\
Blackwater Estuary (1979) & 3 & 6,21 & 25 & Dempsey \& Bamber 1983 \\
\hline
\end{tabular}

Clarke \& King (1985) in a more recent study of Milford Haven herring report that during neap tides there are increased catches which they believe are related to spawning waves. Fishing effort is much greater during periods of neap tides but they conclude increased effort alone cannot account for the elevated landings.

Savage \& Hodgson (1934) when examining landings of East Anglia fishery in the North Sea found increased catches at full moons during the autumn spawning season. However these findings were qualified by Hodgson (1957) who noted that 'fishermen were not always right in associating the full moon with heavy catches. The amount of "lunar influence" was found to depend very much on the date of the full moon, a fact which at first sight appears surprising, for surely one full moon is very like any other, but the enquiry showed quite clearly that an early full moon in October and a late full moon in November had practically no effect on the catches,

Savage \& Hodgson (1934) also examined other data from the North Sea herring (North Shields and Grimsby fisheries) and could find no evidence for a lunar or tidal effect.

Ware \& Henriksen (1978) examined spawning runs off Escuminac, New Brunswick in the Gulf of St. Lawrence, where some fishermen believed the biggest runs occurred on full moons, and found they could occur at any phase of the moon. High catches and full moons coincided with no more frequency than by chance alone.

In British Columbia a number of stocks clearly display increased spawning activity during neap tides but there are also stocks whose spawning appears to bear no relation to lunar or tidal phase (D. Hay, Pacific Biological Station, Nanaimo, British Columbia, pers. comm.)

Thus, lunar influence, like differential migration rate, may have a limited effect on some stocks, but does not have the plausibility or more universal applicability of age-specific maturation as the cause of spawning waves in herring.

The spawning time of herring seems to be, in a general sense, governed by physical factors, tempera- ture being perhaps the most important. Thus, as has been shown earlier, the mean day of arrival (MDA) of herring at spawning grounds can be roughly predicted in many cases from temperature data. Now, in addition, I am suggesting that a 'fine tuning', that is, age-specific annual ripening of the gonad, determines the duration and pattern of spawning around the MDA. As I have shown, specifically for the Norwegian spring spawners, and with supporting evidence from other stocks, oldest fish spawn first and youngest last.

However, there are some exceptions to this pattern. Runnstrøm (1933) and Ottestad (1934) (both cited in Lebedev 1969) report that Atlantic herring in some years show a reverse pattern, in that small fish arrive first at the spawning ground followed by the larger fish. A possible explanation of this is based on evidence that recruit spawners overwinter in a different locality from the mature stock (Runnstrøm 1941a). Environmental conditions in the 2 localities undoubtedly differ enough in some years to disrupt the normal sequence of the relative maturation times of the 2 groups of spawners. The very fact that Norwegian spring herring recruit to the spawning population at anywhere from 3 to $7 \mathrm{yr}$ of age is a result of highly variable environment to which juveniles can be subjected. Warmer temperatures and richer food conditions lead to faster grown and earlier recruitment for some year classes (Runnstrøm 1941a).

Age segregation through the spawning season has important implications. Waves of spawning, stemming from dominant year classes, lead to a succession of larval cohorts (Hourston 1958, Lambert et al. 1982, Dempsey \& Bamber 1983). Lambert \& Ware (1984) suggested that this production of batches of eggs and resultant larval cohorts was part of a bet-hedging strategy which ought to lead to enhanced survival and better recruitment. Dispersing the spawning effort through time as well as geographically has obvious advantages. Firstly, spawning beds can be subject to considerable predation (Bowman 1922, Hempel \& Hempel 1968, Dragesund \& Nakken 1973, Johannessen 1980). Distributing eggs over space and time can reduce their overall vulnerability. For example, in the southern Gulf of St Lawrence, the eggs of autumnspawning herring can be eaten in quantity by mackerel 
(Messieh 1986, author's pers, obs.). Since mackerel at this time are beginning their migration out of the Gulf back to overwintering grounds, later egg depositions by herring may be subject to little or no predation from mackerel. Secondly, destructive physical effects can be hedged against. Egg beds are vulnerable to destruction by wave action associated with violent storms (Runnstrøm 1941b, author's pers. obs. on Fishermans Bank, Northumberland Strait); or sudden influxes of cold water can cause mass mortality of eggs (Messieh 1986). Since herring often spawn during times of unsettled weather in spring and late autumn, the odds of some eggs surviving storm damage would be much greater when they are deposited in batches over time rather than all at once. After hatching, larvae are subject to varying levels of food and predation pressure. Again, the larval cohorts stemming from spawning waves are a hedge against vicissitudes of the environment. Such environmental effects are reflected in the variable survival of larval cohorts. Mortality estimates on 7 larval cohorts of autumn-spawned herring within Sheepscot Estuary, Maine, USA, ranged from 0.9 to $3.1 \% \mathrm{~d}^{-1}$ during October to December (Graham \& Townsend 1985). Henderson et al. (1984) estimated mortalities of 6.1 and $7.4 \% \mathrm{~d}^{-1}$ during April to June for 2 cohorts of spring-spawned herring larvae in the Thames Estuary, England. There is a great enough range in these mortality values to drastically alter the relative abundance of cohorts in a few months. For example, 2 cohorts of initially equal magnitude suffering mortalities of 0.9 and $3.1 \% \mathrm{~d}^{-1}$, respectively, would have a 7 -fold difference in abundance after 3 mo.

Lambert (1984) suggested that competition between larval cohorts would be reduced because the size differences of larvae of temporally adjacent cohorts would virtually assure them of independent food supplies. Thus if density-dependent mortality were to occur it ought to become evident first within a particularly large cohort. Such mortality would be a function of the density of larvae within the cohort rather than density of the total larval population. This in fact has been demonstrated in some excellent support for the hypothesis. Rosenberg \& Doyle (1986), in a study of SW Nova Scotia herring, provide evidence for compensatory density dependence which appears most strongly in the relationships of abundances of individual mature age groups and total recruitment.

Thus the beginnings of a link between the spawning wave phenomenon and recruitment starts to form. Hitherto it has only been possible to demonstrate a relationship between spawning potential and recruitment in some small stocks of Pacific herring in British Columbia and in the Downs stock in the North Sea, but not in many other major herring stocks (Dragesund 1970). Iles \& Sinclair (1982) suggest that 'stock recruit- ment mechanisms that include adult stock-dependent feedback are generally inappropriate for herring'. However, in all cases it was a relationship between total stock and recruitment that was examined. Perhaps, a more fruitful line of investigation would be a consideration of possible age-structured stock recruitment relationships. Incentive toward this goal is provided by Dragesund (1970). He showed that 2 important factors in the determination of year class strength in herring were duration and geographical extent of spawning. The longer the spawning season and more widespread the deposition of eggs, the greater the likelihood of good recruitment. As I have shown, the more age classes involved in spawning, the longer will be the spawning season and more widespread will be the spawning since different age groups tend to spawn in different areas. Therefore, it would appear that the maintenance of a wide, well-balanced age structure tends to promote a resiliant or more stable population; whereas, the converse, reduction of age classes, renders a population more vulnerable to recruitment failure.

Acknowledgements. I thank Ken Frank and Dan Ware for discussions and advice. I am indebted to the pioneering work of the first herring researchers in Norway; their comprehensive studies and thorough sampling procedures made this paper possible. My thanks also to an anonymous reviewer who pointed out an error in the calculation of mean date of spawning and supplied other helpful comments.

\section{LITERATURE CITED}

Aasen, $O$. (1982). On the correlation between the arrival and spawning of the Norwegian winter herring. J. Cons. perm. int. Explor. Mer 27: 162-166

Alexander, R. McN. (1967). Functional design in fishes. Hutchinson \& Co., London

Anthony, V C., Waring, C. (1980). The assessment and management of the Georges Bank herring fishery. Rapp. P.-v. Réun. Cons. int. Explor Mer 177: 71-111

Auger, F., Powles, H. (1980). Estimation of the herring spawning biomass near Isle Verte in the St. Lawrence Estuary from an intensive larval survey. CAFSAC RES Doc. 80/59

Baker, R. R. (1978). The evolutionary ecology of animal migration. Hodder \& Stoughton, London

Berenbeim, D. Ya., Sigaev, I. K. $(19 \overline{7})$. On correlation between water temperature and the spawning times for Georges Bank herring. ICNAF Res. Doc, $77 / \mathrm{VI} / 42$

Blaxter, J. H. S., Hempel, G. (1963). The influence of egg size on herring larvae (Clupea harengus). J. Cons. int. Explor Mer 28 (2): 211-240

Blaxter, J. H. S., Holliday, F. G. T (1963). The behaviour and physiology of herring and other clupeoids. Adv. mar Biol. 1: 261-393

Blaxter, J. H. S., Hunter, J. R. (1982). The biology of the clupeoid fishes. Adv. mar. Biol. 20: 1-223

Bowman, A. (1922). The occurrence of 'spawny' haddock and the locus and extent of herring spawning grounds. Fish. Scotland Sci. Invest. IV

Boyar, H. C. (1968). Age, length, and gonadal stages of her- 
ring from Georges Bank and the Gulf of Maine. ICNAF Res. Bull. 5: 49-61

Burd, A. C. (1962). Growth and recruitment in the herring of the southern North Sea. Fishery Invest., Lond. (Ser 2) 13 (5): $1-42$

Clarke, D. R., King, P. E. (1985). Spawning of herring in Milford Haven. J. mar. biol. Ass. U. K. 65: 629-639

Cole, L. C. (1951). Population cycles and random oscillations J. Wild. Mgmt 15 (3): 233-252

Dawson, W. A. (1986). Changes in western mackerel (Scomber scombrus) spawning stock composition during the spawning season. J. mar. biol. Ass. U. K. 66: 367-383

Day, L. R. (1957). Populations of herring in the southern Gulf of St. Lawrence. Bull. Fish. Res. Bd Can. 111 121-137

Dempsey, C. H., Bamber, R. N. (1983). Spawning of herring (Clupea harengus) in the Blackwater Estuary, spring, 1979. J. Cons. int. Explor. Mer 41 85-92

Dragesund, O. (1970). Factors influencing year-class strength of Norwegian spring spawning herring (Clupea harengus Linnel. FiskDir. Skr. (Ser. Havunders.) 15: 381-450

Dragesund, O., Hamre, J., Ulltang, O. (1980). Biology and population dynamics of the Norwegian spring-spawning herring. Rapp. P.-v. Réun. Cons. int. Explor. Mer 177: 43-71

Dragesund, O., Nakken, O. (1973). Relationship of parent stock size and year class strength in Norwegian springspawning herring. Rapp. P.-v. Réun. Cons. int. Explor. Mer $164: 15-30$

Elliot, J. M. (1984). Numerical changes and population regulation in young trout (Salmo trutta) in a Lake District stream, 1966-83. J. Anim. Ecol. 53: 327-350

Graham, M. (1936). Investigations of the herring of Passamaquoddy and adjacent regions. J. Biol. Bd Can. 2 (2): 95-139

Graham, J. J., Townsend, D. W. (1985). Mortality, growth, and transport of larval Atlantic herring (Clupea harengus) in Maine coastal waters. Trans. Am. Fish. Soc. 114 (4): $490-498$

Gritsenko. O. F., Shilin, N. I. (1979). Ecology of reproduction of herring in Nyiski Bay (Sakhalin). Sov. J. mar Biol. 5 (1): $42-47$

Haegele, C. W., Schweigert, J. F. (1985). Distribution and characteristics of herring spawning grounds and description of spawning behaviour. Can. J. Fish. Aquat. Sci. 42 (Suppl. 1): 42-47

Harden-Jones, F. R. (1977). Performance and behaviour on migration. In: Steele, J. H. (ed.) Fisheries mathematics Academic Press, London, p. 145-170

Hay, D. E. (1985). Reproductive biology of Pacific herring (Clupea harengus pallasi). Can. J. Fish. Aquat. Sci. 42 (Suppl. 1): 111-126

Hempel, I., Hempel, G. (1968). An estimate of mortality in herring eggs. The biology of early stages and recruitment mechanisms of herring. Symposium, Cons. int. Explor. Mer 32: $1-5$

Henderson, P. A., Whitehouse, J. W., Cartwright, G. H. (1984). The growth and mortality of larval herring (Clupea harengus L.) in the River Blackwater Estuary, 1978-1980. J. Fish Biol. 24: 613-622

Hickling, C. F. (1946). The herring fisheries at Milford Haven. J. mar. biol. Ass. U. K. 26: 408-420

Hjort, J. (1914). Fluctuations in the great fisheries of northern Europe. Rapp. P.-v. Réun. Cons. int. Explor. Mer 20: 1-227

Hodgson, W. C. (1927). Size and age composition of the East Anglian autumn herring. J. Cons. int. Explor. Mer $2(1)$ : $69-74$

Hodgson, W. C. (1957). The herring and its fishery. Routledge and Kegan Paul, London
Hourston, A. S. (1958). Population studies on juvenile herring in Barkley Sound, British Columbia. J. Fish. Res. Bd Can. $15(5): 909-960$

Iles, T. D. (1964). The duration of maturation stages in herring J. Cons. int. Explor Mer 29 (2): 166-188

Iles, T D., Sinclair, M. (1982). Atlantic herring: stock discreteness and abundance. Science 215:627-633

Jean, Y (1956). A study of spring and fall spawning herring (Clupea harengus) at Grande Riviere, Bay of Chaleur, Quebec. Quebec Dept. Fish. Contrib. 49: 1-75

Johannessen, A. (1980). Predation on herring (Clupea harengus) eggs and young larvae. Cons. int. Explor Mer (H: 33): $1-12$

Johannessen, A. (1986). Recruitment studies of herring (Clupea harengus) in Lindaaspollene, Western Norway, 1-3. FiskDir. Skr (Ser. Havunders.) 18: 139-240

Lambert, T C. (1984). Larval cohort succession in herring (Clupea harengus) and capelin (Mallotus vollosus). Can. J. Fish. Aquat. Sci. 41 (11): 1552-1564

Lambert, T C., Ware, D. M., McRuer, J. K. (1982). Spawning and early life history of herring and capelin in St. Georges Bay, Nova Scotia. Can. Tech. Rept. Fish. Aquat. Sci. 1128 $1-82$

Lambert, T C., Ware, D. M. (1984). Reproductive strategies of demersal and pelagic spawning fish. Can. J. Fish. Aquat Sci. 41 (11): 1565-1569

Lea, E. (1929). The oceanic stage in the life history of the Norwegian herring. J. Conseil 4 (1): 1-42

Lea, E. (1930). Mortality in the tribe of Norwegian herring Rapp. P.-v. Réun. Cons. int. Explor. Mer 65: 1-42

Lebedev, N. V (1969). Elementary populations of fish (Izdatel'stvo 'Pishchevaya Promyshlennost' Moskva 1967). Istael program for scientific translations. Available from the U. S. Dept. of Comm., Springfield, Virginia

Libby, D. A. (1982). Decrease in length at predominant ages during a spawning migration of the alewife, Alosa pseudoharengus. Fish. Bull. U. S. 80 (4): 902-905

Lockwood, S. J., Nichols, J. H., Dawson, W. A. (1981). The estimation of a mackerel (Scomber scombrus) spawning stock size by plankton survey. J. Plank. Res. 3 (2): 217-233

Messieh, S. N. (1978). The decline of the herring fishery in northern Northumberland Strait and its possible causes CAFSAC Res. Doc. 78/5, Box 1006, Dartmouth, N.S., Canada

Messieh, S. N. (1986). The enigma of Gulf herring recruitment. NAFO SCR Doc. 86/103، Box 1006, Dartmouth, N.S., Canada

Motoda, S., Hirano, Y (1963). Review of Japanese herring investigations. Rapp. P.-v. Réun. Cons, int. Explor. Mer 154: 249-261

Pankratov, A. M., Sigajev, I. K. (1973). Studies on Georges Bank herring spawning in 1970. ICNAF Res. Bull. 10 125-130, Box 1006, Dartmouth, N.S., Canada

Parrish, B. B., Saville, A. (1965). The biology of the north-east Atlantic herring populations. Oceanogr. mar. Biol. A. Rev. 3: $323-373$

Parrish, B. B., Saville, A., Craig, R. E., Baxter, I. G., Priestley, R. (1959). Observations on herring spawning and larval distribution in the Firth of Clyde in (1958). J. mar. biol. Ass. U. K. 38: 445-453

Raup, D. M., Sepkowski, J. J. (1984). Periodicity of extinctions in the geologic past. Proc. natn. Acad. Sci. U.S.A. 81 801-805

Rosenberg, A. A., Doyle, R. W. (1986). Analysing the effect of age structure on stock-recruitment relationships in herring 
(Clupea harengus). Can. J. Fish. Aquat. Sci. $43(3)$ $674-679$

Runnstrom, S. (1941a). Racial analysis of the herring in Norwegian waters. Rep. Norweg. Fish. Invest. 6 (7): 6-110

Runnstrom, S. (1941b). Quantitative investigations on herring spawning and its yearly fluctuations at the west coast of Norway. Rep. Norweg. Fish. Invest. 6 (8): 3-71

Savage, R. E., Hodgson, W. C. (1934). Lunar influence on the East Anglian herring fishery. J. Cons. int. Explor Mer 9: $223-240$

Simpson, A. C. (1959). The spawning of plaice in the North Sea. Fish. Invest. M.A.F.F. London (Ser 2) 22 (7): 1-111

Smith, W. C. (1938). The Manx herring shoals. Proc. Liverpool biol. Soc. $51: 22-70$

Stevenson, J. C. (1962). Distribution and survival of herring larvae (Clupea pallasii Valenciennes) in British Columbia waters. J. Fish. Res. Bd Can. 19 (5): 735-810

Stobo, W. T. (1982). Tagging studies on Scotian Shelf herring NAFO SCR Doc. 82/IX/108: 1-16

Tester, A. L. (1937). The length and age composition of the herring (Clupea pallasii) in the coastal waters of British Columbia. J. Biol. Bd Can. 3 (2): 145-168
Tibbo, S. N. (1949). Atlantic herring investigation committee. Rept. Inv. March 1948-49. Ser. B. Herring population studies. Mimeo Rept., St. Andrews Biological Stn, St. Andrews, N.B., Canada

Tibbo, S. N., Messieh, S. N., Burnett, C. D. (1969). Catch statistics, length and age composition, Gulf of St. Lawrence herring. J. Fish. Res. Bd Can. Tech. Rept. 139

Ware, D. M. (1978). Bioenergetics of pelagic fish: theoretical change in swimming speed and ration with body size. $J$. Fish. Res. Bd Can. 35 (2): 220-228

Ware, D. M. (1985). Life history characteristics, reproductive value, and resilience of Pacific herring. Can. J. Fish. Aquat. Sci. 42 (Suppl. 1): 127-137

Ware, D. M., Henriksen, B. L. (1978). On the dynamics and structure of the southern Gulf of St. Lawrence herring stocks. Fish. mar. Serv. Can. Tech. Rept. 800: 1-83

Winters, G. H., Beckett, J. S. (1978). Migrations, biomass and stock interrelationships of southwest NewfoundlandSouthern Gulf herring from mark-recapture experiments. ICNAF Res. Bull. 13: 74-79 